\title{
Parallelisms and revelatory concepts of the Johannine Prologue in Greco-Roman context
}

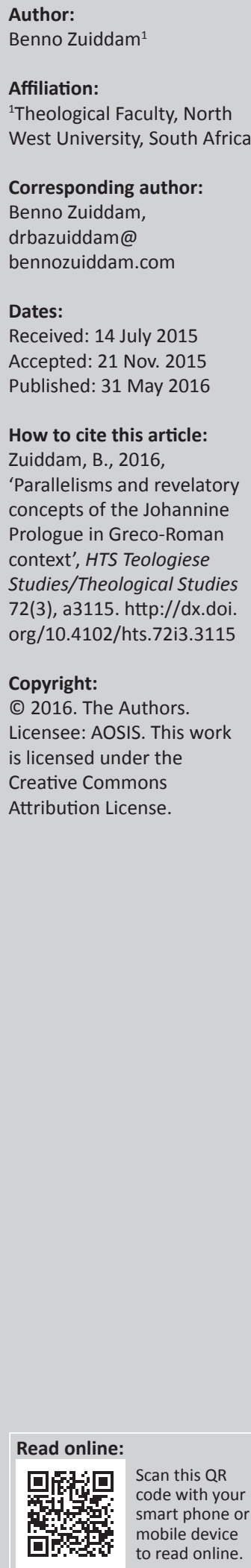

\begin{abstract}
This article builds on the increasing recognition of divine communication and God's plan as a central concept in the prologue to the Fourth gospel. A philological analysis reveals parallel structures with an emphasis on divine communication in which the Logos takes a central part. These should be understood within the context of this gospel, but have their roots in the Old Testament. The Septuagint offers parallel concepts, particularly in its wisdom literature. Apart from these derivative parallels, the revelatory concepts and terminology involved in John 1:1-18, also find functional parallels in the historical environment of the fourth gospel. They share similarities with the role of Apollo Phoebus in the traditionally assigned geographical context of the region of Ephesus in Asia Minor. This functional parallelism served the reception of John's biblical message in a Greco-Roman cultural setting.
\end{abstract}

\section{Introduction}

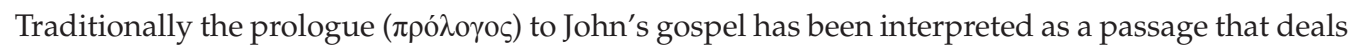
with the pre-existence of Christ and his subsequent incarnation. The headers added in several bible translations reflect this: 'The Word Became Flesh' (NRSV, NIV, ESV). Although this seems a valid conclusion on the basis of the contents of the text for readers of the 21st century, the Good News translation with its header 'The Word of Life' does greater justice to the communicative aspect of this passage. The central role of the Logos in communicating between God and humanity is confirmed by a philological ${ }^{1}$ analysis of John 1:1-18, read within the context of this gospel and its Greco-Roman world. A careful reading suggests that the author is proclaiming a cosmic theology of revelation, and presents the incarnation of Christ and his pre-existence with God as part of a revelatory process. John Ashton (2014:145-156) phrases this differently, but essentially suggests the same when he says (Ashton 2014:3) that the prologue is essentially about 'God's plan for humankind', and not about creation as previously argued. Of course the latter is an important issue in the prologue, but its context is that of God revealing his plans. He does so as creator, and consequently in a special relationship with mankind. There are several arguments for this view. In the first place, an analysis of the passage will show that the author distinguishes a source, mediation process, and earthly effects of divine revelation in this passage. This sender (God), message or messenger (Logos), and receiver (world or humanity) structure of the text suggests that John does not present the incarnation as a goal in itself but subservient to a communication aim. Generally speaking, this agrees well with the overall structure of this particular gospel, where revelation from God to humans on earth is a central thought.

In the second place, on a philological level, the author uses revelatory terminology for his key concepts, applying philological and religious parallelism to this end. This has parallels in the Qumran community. Daniel Harrington (2005):

For both groups the most important object of knowledge is God and God's plan being unfolded in history. And the most effective way toward this knowledge is through divine revelation. (p. 136)

In the third place, it made sense to do it in this way because of the first historical context of the fourth gospel. Van Tilborg (1996) already firmly positioned John's gospel in Ephesus in his 'Reading John in Ephesus'. Although he mentions Apollo and the presence of his temples (Van Tilborg 1996:71, 94, 135-137, 159, 205), 'Reading John in Ephesus' does not include a treatment of the particulars of local worship, that of Phoebus Apollo. Peter Phillips mentions the Apollo

\footnotetext{
1.Literary critical approaches to the prologue have proven largely inconclusive. Bultmann, Käseman, Schnackenburg and Haenchen supposed a hymn lay at the basis in some way, but scholars' opinions differ as to the point where the original hymn should be located in the prologue. Peter Borgen (1972:129) follows C.K. Barrett in his conclusion that it is impossible to draw this sort of division that might enable the readers to assign some verses to a source written in poetry, and others to a prose-writing evangelist: 'the structure of the Prologue of John must primarily be understood on the basis that it is meant to be an exposition of Gen. I I ff. The question of poetry or prose is therefore of subordinate significance'. Masanobu Endō (2002:184) concludes likewise: 'The question is whether the criteria which scholars apply to the evaluation of the style of the prologue can be suitable for understanding the style of the Fourth Gospel. For example it seems subjective to judge the literary style'.
} 
Temple in Pompei (2006:1-2), but otherwise the Greek oracle religion does not feature in his in depth study on the prologue of the fourth gospel. Recent contributions of other experts suggest that this situation has not changed (e.g. Bauckham \& Mosser 2008).

\section{Methodology}

This article will place revelatory concepts of John 1:1-18 in the context of the gospel. Then it will call attention to the parallels of John's revelatory notions and 'light' imagery in the Septuagint (including the Apocrypha). It will subsequently turn the spotlight, as it were, to the Greek oracular environment of Ephesus as historical context of John's gospel. Although not as a case for dependence, neither the text of the gospel or any church fathers suggest that John derived concepts from the Greek religion, this study argues for functional parallels between concepts in the prologue and the Greek oracle religion of Phoebus Apollo. Because of this religion, combined with Ephesus as the traditional location for the origin of the Gospel of John, the original readers would have been receptive for the overall revelatory aim of the prologue and this particular gospel. This predisposed them to readily grasp some of John's main concepts.

As this journal attracts a wider readership than specialists in this aspect of Johannine scholarship, the text of the prologue is included for accessibility, John 1:1-18 (NRSV): ${ }^{2}$

${ }^{1}$ In the beginning was the Word, and the Word was with God, and the Word was God. ${ }^{2} \mathrm{He}$ was in the beginning with God. ${ }^{3} \mathrm{All}$ things came into being through him, and without him not one thing came into being. What has come into being ${ }^{4}$ in him was life, and the life was the light of all people. ${ }^{5}$ The light shines in the darkness, and the darkness did not overcome it. ${ }^{6}$ There was a man sent from God, whose name was John. ${ }^{7} \mathrm{He}$ came as a witness to testify to the light, so that all might believe through him. ${ }^{8} \mathrm{He}$ himself was not the light, but he came to testify to the light. ${ }^{9}$ The true light, which enlightens everyone, was coming into the world. ${ }^{10} \mathrm{He}$ was in the world, and the world came into being through him; yet the world did not know him. ${ }^{11} \mathrm{He}$ came to what was his own, and his own people did not accept him. ${ }^{12}$ But to all who received him, who believed in his name, he gave power to become children of God, ${ }^{13}$ who were born, not of blood or of the will of the flesh or of the will of man, but of God. ${ }^{14}$ And the Word became flesh and lived among us, and we have seen his glory, the glory as of a father's only son, full of grace and truth. ${ }^{15}$ (John testified to him and cried out, "This was he of whom I said, "He who comes after me ranks ahead of me because he was before me"'.'. ${ }^{16}$ From his fullness we have all received, grace upon grace. ${ }^{17}$ The law indeed was given through Moses; grace and truth came through Jesus Christ. ${ }^{18}$ No one has ever seen God. It is God the only Son, who is close to the Father's heart, who has made him known. ${ }^{3}$

2. The Greek text used for the New Testament quotes in this article is Nestle Aland 28 while the Greek and Hebrew texts of Old Testament Scripture are from the current versions of the Septuagint and Biblica Hebraica Sturgartensia published by the German Bible Society.

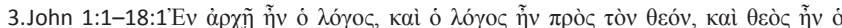

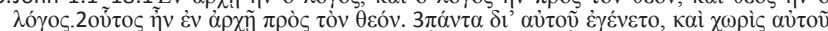

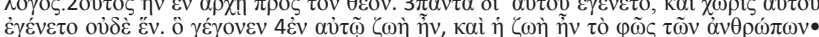

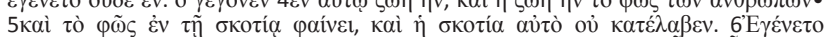

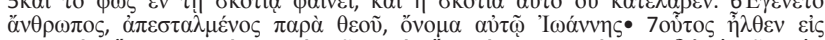

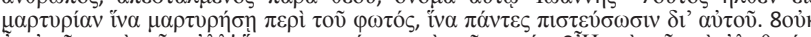

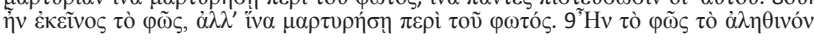

\section{Parallelisms and revelatory concepts of John 1:1-18 in the context of the Gospel}

In this section, the parallelisms and revelatory concepts of John 1:1-18 will be analysed philologically in the context of the gospel and wider Biblical literature. Following this analysis, the particular Greco-Roman context of John's gospel, as suggested by the early Church, will be considered. Others have already worked on the direct textual context $(1 ; 19-2: 12)$ and its revelatory aspects. Francis Martin and William Wright (2015:42-61) distinguish four days of revelation in chapter one (1:19-51) and a subsequent revelation of glory in chapter two (2:1-12).

\section{Logos}

John 1:1-18 is a passage about communication: ó $\lambda$ ó $\gamma o \varsigma_{\text {, }}$ derived from speaking or communicating. Bauer, Aland and Aland (1988:968) see communication (das Sprechen) as the first meaning of $\lambda$ óyos. One should be aware that Koiné Greek often uses the definite article in a generic and not in a definite way, as English and other modern European languages do. For this reason, a translation like 'Communication' would reflect the intention of the author for our day and age: 'In the beginning was Communication, and Communication was with God, and Communication was God'. (v. 1) And likewise (v. 14): 'And Communication took on a body and temporarily dwelt among us and we have seen his glory, a glory like one would expect the only begotten to have when he comes from his Father, full of grace and truth'. In the traditional Greek

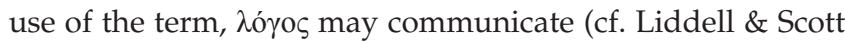
1996:1057-1059): value (1), correspondence or proportion (2), explanation (3), inward thoughts (4); or contain a narrative (5), a message or verbal expression (6), or a divine utterance (or an oath calling on the gods respectively). It may also refer to subject matter (8) or any speech (9). In biblical literature several traditional elements of $\lambda$ ó $\gamma$ os come together in Christ as God's representative agent. It is he who functions as the Word and Wisdom of God, through whom God creates the world and exercises government. He communicates God's thoughts, commandments, and salvation to humanity (cf. 1 Jn 1:1, 2:7, Rv 19:13). Paul Anderson points to the similarity in syntax between the prologue and 1 John 1:1-5 (2008:329): 'much of its language and syntax is closer to 1 John 1:1-5 than to the rest of the Gospel'.

The overall communicative emphasis of the prologue is hard to miss (Giblin 1985:89): 'The author insists on the act of communication'. Although on a horizontal level, the term has seen some development in Greek philosophy, long before

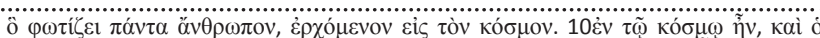

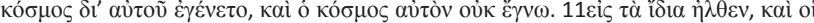

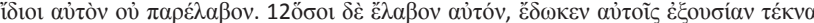

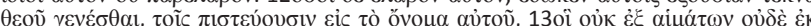

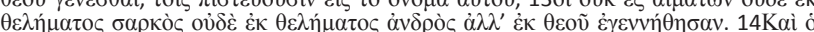

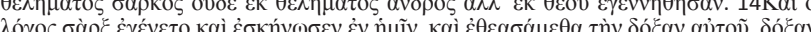

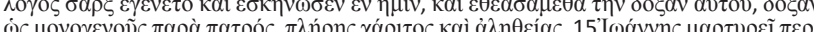

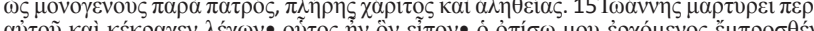

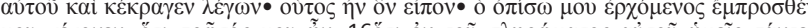

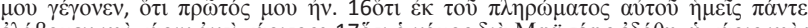

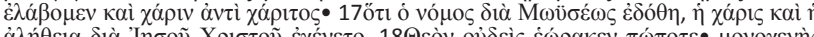

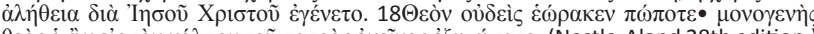

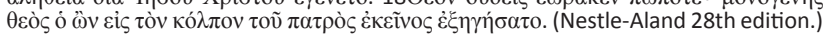


John's gospel (Lincoln 1996:2), this is not relevant for its use

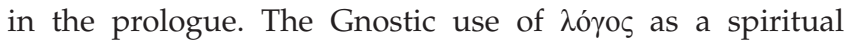
principle applied to rid the soul of the bondage to the material world is likewise a different field of meaning (Van den Broek 1979:280).

From the Old Testament there is also particular association with divine commands in an oracular context, God speaking verbally to the people of Israel (e.g. The Decalogue, cf. Ex 20, 34:28 LXX). When God speaks, obedience is called for. This aspect also strongly reflects in the Gospel according to

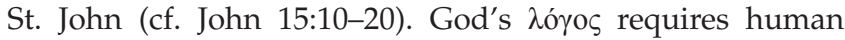
response and discipleship. There is also a revelatory aspect in the activities of the $\lambda$ ó ${ }^{\circ}$ s. In the words of John 1:18: 'No one has ever seen God. It is God the only Son, who is close to the Father's heart, who has made him known'. What would be otherwise inaccessible is made known and communicated from God through the $\lambda$ óyoc. The term goes hand in hand with Revelation and obedience in the writings of the New Testament (cf. Mt 15:6, Mk 7:13, Jn 5:38, 8:55, 10:35, Rm 3:4). Like Moses, the Logos acts as God's agent, but is at the same time more than that. ${ }^{4}$

\section{Communicator creator}

John 1:1 explains the origin of the $\lambda$ ó ${ }^{\circ}$ ○ in place and time, as something literally out of this material world. He points to the ultimate prehistory of Genesis 1:1; even then, God's $\lambda$ ó $\gamma$ already existed. Although two different ideas about the generation of the Logos prevailed in early Christianity, ${ }^{5}$ both agreed that he was there before time and perception started for human beings. Nothing was created without him, 1:3:

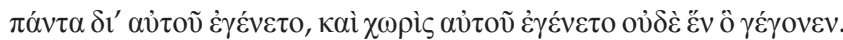
This connection between the Logos and Creation is extensively treated by Masanobu Endō (2002). The echo from Genesis 1 is reinforced by the use of $\dot{\varepsilon} v \dot{\alpha} \rho \chi \tilde{n}(1: 1-2)$ and $\dot{\varepsilon} \gamma \varepsilon \dot{v \varepsilon \tau o ~(1: 3), ~}$ reminiscent of God who spoke in the beginning and it was.

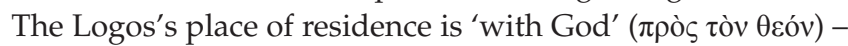
that is, effectively, heaven; although for the writer of John's gospel 'with God' suffices as location. One observes the same

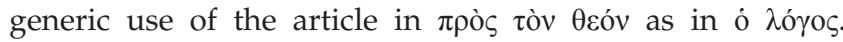
Subsequently, the Word is identified with the only true God

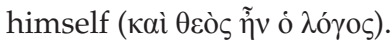

Logos was God. One observes that in all respects (time, origin, and identity) the $\lambda$ ó ${ }^{\circ} \varsigma$ belongs to the realms of God, not to the cosmos or this world. It is divine communication from the realms of glory that is going to arrive in this world in a personal way.

\footnotetext{
4.Craig Evans (1993:145) emphasises the revelatory role of Moses and Jesus: "Like Moses, Jesus is presented as God's "agent," a shaliach who speaks and acts with God's authority. But unlike Moses, Jesus is the shaliach par excellence, in whom God's Word, Torah, Wisdom and Glory have taken up residence and are revealed'.

5.H.E. Wolfson (1951:72) describes the two views on the origin of the Logos in early Christianity: 'They may be described as the twofold stage theory and the single stage theory. According to the twofold stage theory, which reflects a similar conception in Philo, ${ }^{1}$ the Logos at first existed from eternity in God and then, prio conception in Phil, the Logos at first existed from eternity in God and then, prior to the creation of the world, it was generated from the essence of God as a distinct personal being. Representatives of this view are, among the Greek Fathers, Justin Martyr, Tatian, Athenagoras, Theophilus, and Hippolytus, and among the Lati Fathers, Tertullian, Novatian, Lactantius, and as late as the 4th century, Zeno of Verona. According to the single stage theory, the generation of the Logos from God was from eternity. The first to introduce this view were Irenaeus and Origen and it is this view which ultimately prevailed'.
}

\section{Logos, light, and revelation}

The divine communication is aimed at reception. God's communication process through the Logos is not general, but specific. It is aimed at earth, the world of humanity. It facilitates communication between two parties: God and the children of Adam.

The use of the word 'light' is significant. In the Johannine communication process, light and revelation go together (Borgen 1972:115-130). The parallelism between $\lambda$ ó $\varsigma^{\prime} \varsigma, \varphi \tilde{\omega} \varsigma$ and $\zeta \omega \eta$ is worth observing. The Logos provides light in the darkness. The light reveals what would otherwise remain unseen. Just as the plants and trees receive the life-giving light of the sun and grow as a result, the $\lambda$ ó $\gamma$ o $\varsigma$ shines in the spiritual darkness of humanity to provide, not only light, understanding, and direction, but also life and inherent energy.

This connection of light and Word is a very old concept, which is found in the very beginning of the Torah. The first words of God in Genesis concern the creation of light. God speaks and light comes forth:

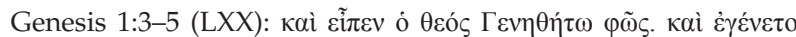

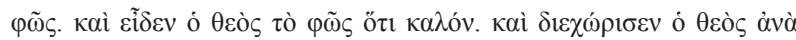

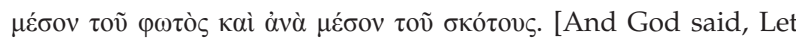
there be light, and there was light. And God saw the light that it was good, and God divided between the light and the darkness. $]^{6}$

Light is created and intended for creatures. Darkness belongs to the unformed state and the earliest beginnings of the creation of the world. It is only when God speaks that light appears. Divine Word and light go together. The creation connection of the Johannine Logos and Genesis is prominent. Paul Anderson (2008) writes:

From the creation narratives of Genesis 1-3, the Logos motif can be seen as rooting in the creative-redemptive work of Yahweh, whose life-producing Word brought forth the created world and the breath of life itself. (p. 332)

After Genesis 1, one has to continue reading well into Exodus before light $\left(\aleph_{n}\right.$ iา $\left./ \varphi \tilde{\omega} \varsigma\right)$ returns with any theological significance, or at all. This happens when 'Israel was in Egypt's land', during the episode of the Ten Plagues. The king was not prepared to do without the slave labour of the Israelites for his favourite projects. Through the hand of Moses, God punishes Pharaoh and his people with pitch-black darkness. He takes away his light and leaves the Egyptians in a state not dissimilar to the world before God spoke his creative words (Gn 1:1-3):

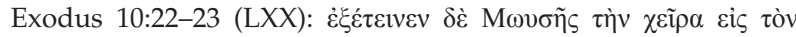

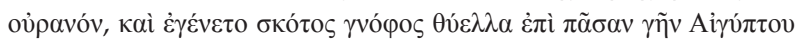

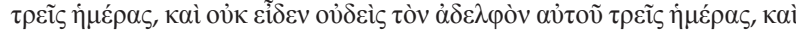

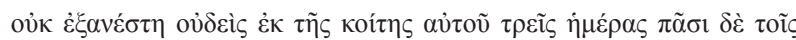

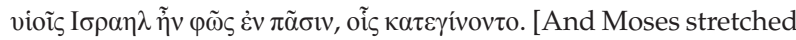
out his hand to heaven, and there was darkness very black, even a storm over all the land of Egypt three days. And for three days no man saw his brother, and no man rose up from his bed for three days: but all the children of Israel had light in all the places where they were.]

6. The author takes responsibility for indented translations from the Septuagint and classical authors, but acknowledges dependence on Brenton (1994) and Perseus Project Texts Loaded under PhiloLogic Greek and Latin Morphology (2010). 
Significantly, the Israelites continue to enjoy God's light, whereas the Egyptians are no longer able to distinguish the world around them. It affects relationships (no one could see

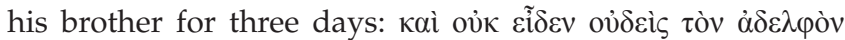

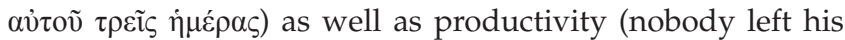

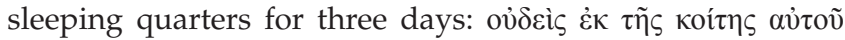

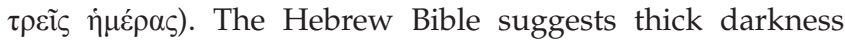

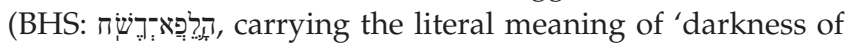
concealment') only, without mentioning the storm, which could point to a supernatural darkness for the Egyptians and a supernatural light for the children of Israel, arguably similar to when God created light before the sun, moon, and stars came into being (cf. Gn 1). This theory would presume light in Goshen and supernatural darkness across the provincial border, as it were. Although this line of thought would reinforce the spiritual significance of the passage, it is perhaps not the most likely interpretation. Even for the Genesis passage, light might not be a supernatural occurrence. Its original light (in Gn 2:2) seems to refer to the creation of light as a phenomenon, while afterwards material producers (sun, moon, stars) and finally perception of light (fish, birds, animals, humans) are put in place.

If the Septuagint translation (3rd century BC) is any indication, early Jewish tradition did not read supernatural darkness and light into Exodus 10:22-23. This was at a time when Hebrew and Greek were not dead languages as yet and the Septuagint translators spoke both languages fluently. They acknowledge that the darkness is a punishment from God, but point the reader to a secondary cause: a heavy storm, a hurricane $(\theta v \varepsilon \lambda \lambda \alpha$, f.). It was the wind which produced the darkness by heaping up clouds and dust. In the Torah, primary (spiritual) and secondary (material) causes are all a natural part of the same world view. One often finds similar situations. To the Septuagint author's mind, there is no doubt that God opened the Sea, but he is also convinced that this happened instrumentally by a strong wind from the East (Ex 14:21, cf. 13:17-14:29). Similarly, in this earlier context of Exodus 10:22-23, there is no reason to presume a supernatural source of darkness, or of light with the Israelites, for that matter. Moses lifted his hand to heaven, the storm raged as God responded, and Egypt was covered in darkness. Just as the immediate cause for the darkness was a hurricane, sweeping up dust and driving dark packs of cloud over the

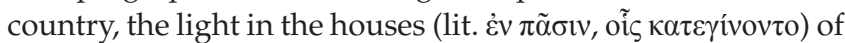
the Israelites may have come from oil lamps, as the Israelites were forewarned by Moses and prepared for the event.

Primary and secondary causes aside, for the author it is ultimately God who causes darkness for the disobedient, taking away creation blessings from the Egyptians; and who also continues to provide light for his people. The light of the Egyptians was concealed by darkness, but just as God's light once overcame the darkness of the unformed world (Gn 1:2:

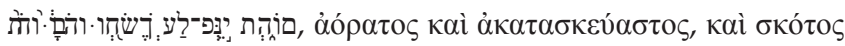

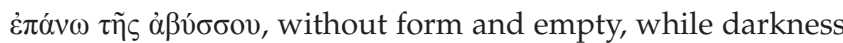
was over the abyss), he now judges his enemies and provides light for his people, the children of his covenant with Abraham, Isaac, and Jacob.
The light of the world, the lux mundi presented by John in the fourth gospel, has similar traits. In the prologue the darkness of the world and the antagonistic welcome that the Logos is about to receive, recall the pre-creation state of the world as well as God's later judgements. Although John does not specifically mention the Fall, he describes a fallen world, which is in need of God's recreation that will provide life and light. Although the darkness of this present, fallen cosmos may be thick and gloomy, it will be unable to overcome the light of

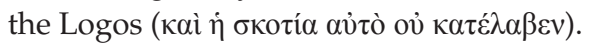

This connection between Word and light is also particularly prominent in the Old Testament wisdom literature. When God speaks, humans receive insight, moral direction, and spiritual guidance for their situation. This was also the Jewish experience of the written Word of God as it was passed from one generation to the next. For instance:

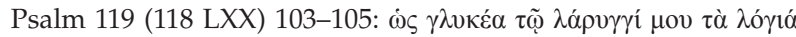

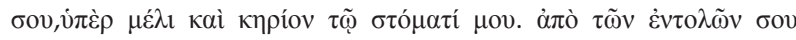

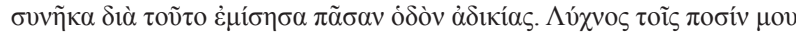

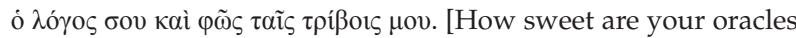
to my throat! more so than honey to my mouth! I gain understanding by your commandments: therefore I have hated every way of unrighteousness. Your law is a lamp to my feet, and a light to my paths.]

\section{Logos source of life}

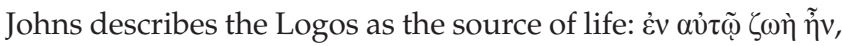

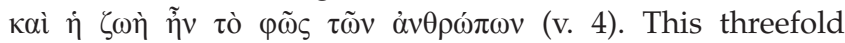
parallelism of Word, light, and life is also found in the Old Testament wisdom literature. The God who creates also provides life through his breath and light for his creatures (Anderson 2008:332) to distinguish the world around them. Thus, he enables them to interact with their environment both intelligently and spiritually:

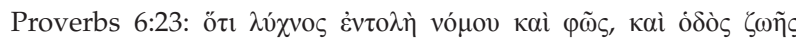

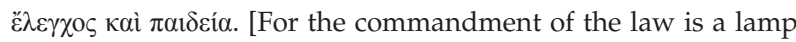
and a light; a way of life; reproof also and correction.]

As breath is used for speaking, God spoke and there was life; and his life-giving breath made Adam a living soul. The Wisdom of Solomon ( $\Sigma$ OФIA $\Sigma \mathrm{A} \Lambda \Omega \mathrm{M} \Omega \mathrm{NO} \Sigma \mathrm{WIS}$, included in the Septuagint) elaborates on this parallelism:

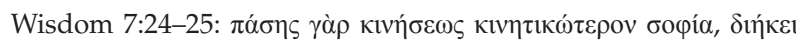

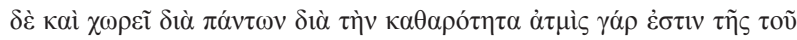

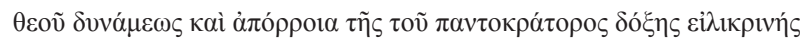

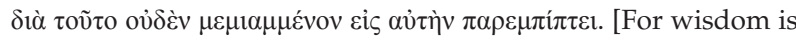
more moving than any motion: she passes and goes through all things by reason of her pureness. For she is the breath of the power of God, and a pure influence flowing from the glory of the Almighty: therefore can no defiled thing fall into her. For she is the brightness of the everlasting light, the unspotted mirror of the power of God, and the image of his goodness.]

The Wisdom of Solomon also reflects on the darkness in Egypt and the light that was provided for God's people. It also spiritualises the imagery of the desert journey of the Israelites as God gave the Israelites a light (column of fire) by night and cloud coverage against the rays of the sun by day. 
God's guidance is the overall aim of these provisions. The Egyptians, by contrast, were deprived of light and imprisoned by darkness, showing God's judgment and echoing the precreation state of the world before the Logos changed it during the six days of creation;

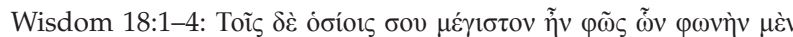

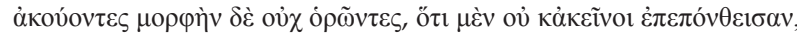

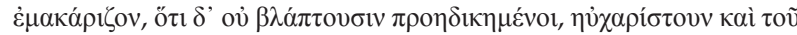

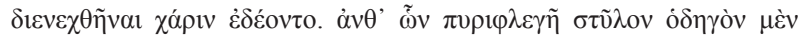

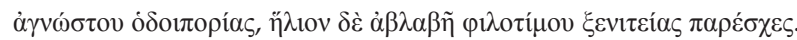

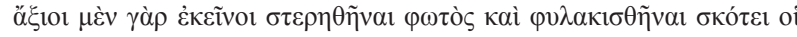

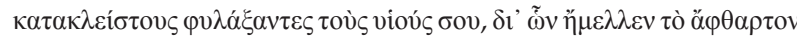

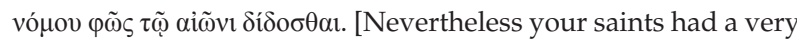
great light, whose voice they hearing, and not seeing their shape, because they also had not suffered the same things, they counted them happy. But for that they did not hurt them now, of whom they had been wronged before, they thanked them, and besought them pardon for that they had been enemies. Instead whereof you gave them a burning pillar of fire, both to be a guide of the unknown journey, and a harmless sun to entertain them honourably. For they were worthy to be deprived of light and imprisoned in darkness, who had kept your sons shut up, by whom the incorrupt light of the Law was to be given unto this generation.]

The end of the passage mentions the Word of God, as the Israelites were entrusted with the Law that God initially wrote with his own finger and gave to Moses (Ex 31:18). The

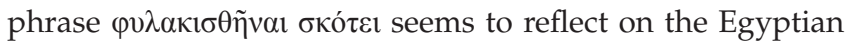
darkness as a judgment on the world that prefers to live without him, but focuses on the Law providing permanent

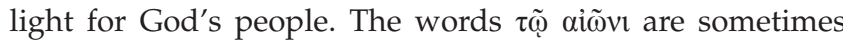
translated 'world' (e.g. Brenton), but in this context it would be truer to the proper sense of 'lifetime' or 'age' to translate with 'generation', as it is righteous people, 'sons of God' ( $\tau$ ov̀ $\varsigma$ vioúc бov), whom the writer has in mind.

The light of God gives insight and understanding. This is also a dominant thought in the closing words of Jesus Sirach. Just before the final hymn (chapter 51) he concludes his teachings with the words:

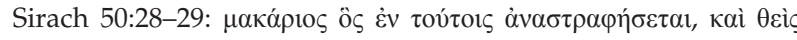
$\alpha$

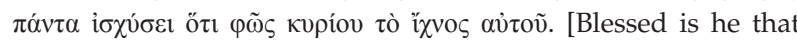
shall be exercised in these things; and he that stores them in his heart shall become wise. For if someone does them, he shall have strength to all things: for the light of the Lord shows his track.]

In a way similar to Wisdom and Sirach, in John's gospel

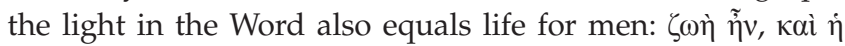

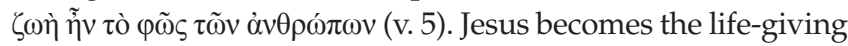
Revealer, as he is often referred to in post-Bultmanian scholarship (Bultmann 1941). The parallelism between Word, light, and life is an integral part of the fourth gospel, perhaps reaching its climax in John 8:12. There the Logos proclaims himself directly as the 'light' of the world to disperse darkness. Those who will follow him will not walk in darkness but have

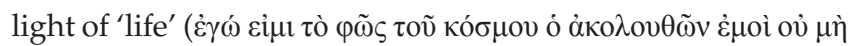

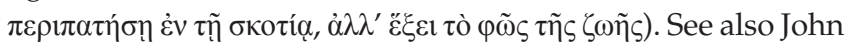
9:5, 12:46.

\section{Identification and communication with humanity}

\section{Primary communication: Incarnation}

The incarnation in itself has some parallel qualities, Logos and Sarks at the same level, a Creator who comes to his

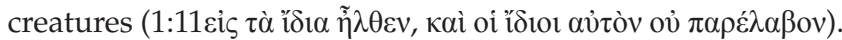
In doing so, he asserts a claim of ownership and authority. The Logos has ownership claims on both the created world and humanity: these and they are his. This also contains an antithetical parallelism at a philological level: $\tau \dot{\alpha}$ i $\delta 1 \alpha$ versus oi idiol, implying rejection of ownerships-rights and rebellion in the human sphere of oi ' $\delta$ tor. This antithetical parallelism is continued in the human reception of the Logos in verse

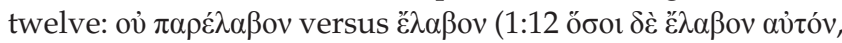

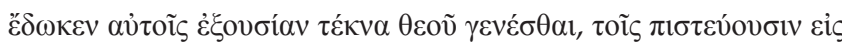

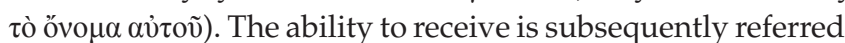
to as only possible through divine instigation (1:13 oî oủк $\dot{\varepsilon} \xi$

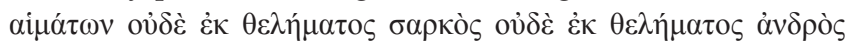
$\left.\dot{\alpha} \lambda \lambda^{\prime} \dot{\varepsilon} \kappa \quad \theta \varepsilon \circ \tilde{\varepsilon} \gamma \xi \varepsilon v v \eta \dot{\theta} \theta \eta \sigma \alpha\right)$, thus contrasting a spiritually unable humanity with a divine re-creator who provides birth from above, a theme that is continued in John 3, but initiated in the prologue.

After the spoken and written Word of God, life-giving to humanity in its qualities, the Logos himself comes into the world. The Word not only shines his light, but becomes incarnate. His arrival and presence take on an intimate form. He doesn't come to his creation in general, but his arrival in

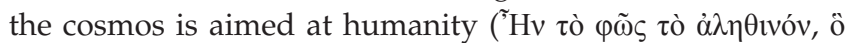

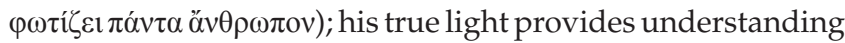
and ability to distinguish to all people. It is not unlike the general benevolence of God as heavenly father, which is displayed in the Sermon on the Mount (Matthew 5:45: ö $\pi \omega \varsigma$

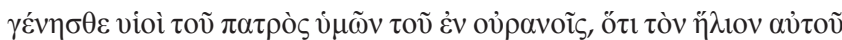

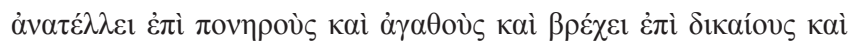

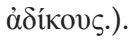

In the Logos, however, the light doesn't just come up in an impersonal way for all people who happen to find themselves on the bright side of the earth, as in the imagery of Matthew $5: 45$. Here in John, the picture is far more intimate. Not only is the light of the Logos specifically aimed at humanity, the Logos also becomes part of humanity himself. It is the incarnate Word who is going to speak God's message and provide light and life to those who hear. God identifies himself permanently with humanity by becoming a permanent part of it through taking on the body of a man. According to John, the Logos was interacting with this world from the start, but

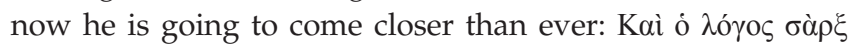

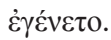

The Logos took on a human body and in this sense the author of John's gospel has a permanent identification of the Word with humanity in mind. Even after the resurrection, the Logos continues to have a body, capable of eating and drinking (cf. John 21). Still the prologue indicates that the bodily

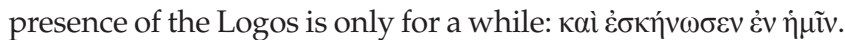
He put up his tent, lived in this region for some time, but then 
packed up and travelled on, like Abraham and the patriarchs of old. The picture is also reminiscent again of the desert journey of the Israelites. God provided light through the fiery column, but it was only for the duration of the journey. And God's actual presence resided in the tent of witness, the tabernacle. Whenever God's light and cloud directed the Israelites to move on, the tent was unpitched. In a similar way the incarnate Logos of John's gospel did not come to stay. In Johannine terms, his body would continue to exist, but not on earth. Although the fourth gospel does not mention the Ascension specifically, it is implied by the temporary residence that is not only indicated by the prologue, but by several other passages throughout the gospel.

\section{Primary communication: the work of father and spirit}

The intimacy also reflects in the anticipated reception and rejection of the Logos. Unlike the sunlight, which shines on all people indiscriminately, his light is not automatically received. This constitutes a central line of thought in John's gospel. Only those who are born of the Spirit will make the connection (cf. John 3), but the idea is also stressed elsewhere in the gospel. Miller (1993):

No doubt the best summary of the centrality and power with which 'word' functions in the fourth gospel is at 6:63: 'It is the Spirit that gives life; the flesh profits nothing. The words that I speak to you, they are spirit and they are life'. (p. 452)

In John's gospel regeneration or re-creation is an activity in which Father, Son, and Spirit participate. No one can come to Jesus unless the Father draws him ((John 6:44). Those who the Father gives to him will draw near (Jn 6:37-39). Disciples don't choose Jesus, but Jesus chooses them and causes his

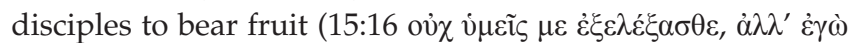

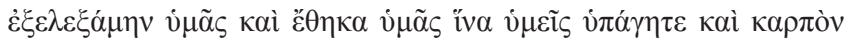

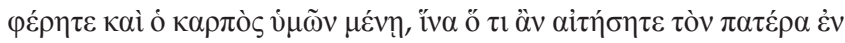

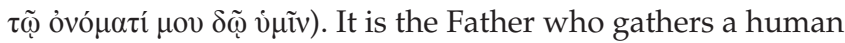
following for the Logos. Similarly, those who are given to the Logos by the Father are prayed for and projected to be Jesus in his anticipated glory after his suffering and death (Jn 17).

Consequently John sees the intermediation process between God and humanity as an intimate interaction of Word, Spirit, and Father. It is a re-creation process. God's light ends concealment of what was otherwise hidden in darkness and

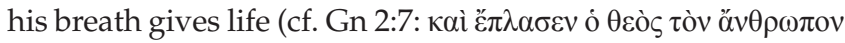

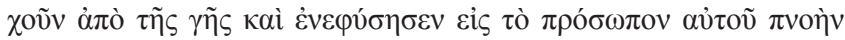

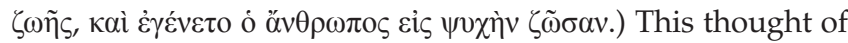
spiritual rebirth is particularly reflected in verse 13: oî ov̉к $\dot{\varepsilon} \xi$

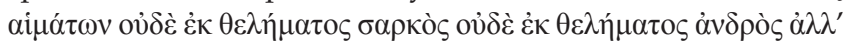
$\dot{\varepsilon} \kappa \theta \varepsilon \circ \tilde{v} \dot{\varepsilon} \gamma \varepsilon v v \eta \dot{\theta} \theta \eta \sigma \alpha v$. Born of God, it speaks the language of family ties, of intimate involvement of God with the subjects of this spiritual birth. Those who welcome the Logos and his light in their life become part of God's family. According to

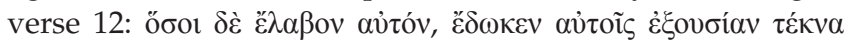

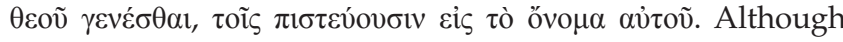
the incarnation of the Logos was in the form of a man - an image of the active creator - he was born from a woman. The subsequent spiritual work in humanity, however, is without

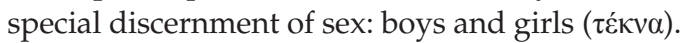

\section{Secondary communication: witness}

The prologue, however, doesn't consider God's communicationstrategies a sole divine venture. The Gospel calls attention to the role of mere mortals as well, who are being taken into the service of the Light. Firstly the author points to the role of John the Baptist as a herald and witness to the Logos. He was a man sent from God, but not in the sense that he came from heaven, like the Logos. John belongs to this earth. He is not Logos, but

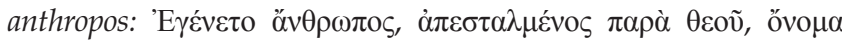

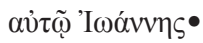

The Baptist's function is one of relay, giving witness about

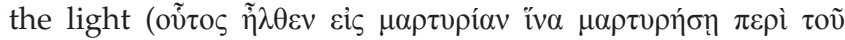

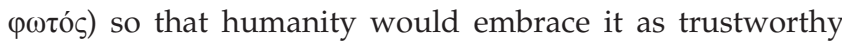

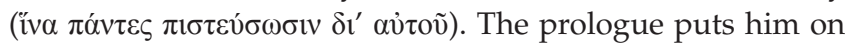
the horizontal level of this world, not the vertical, heavenly dimension of the Logos. John the Baptist belongs to creation, points to the light and recommends it, maybe even mirrors it,

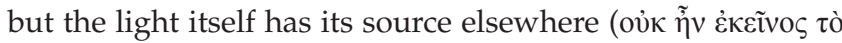

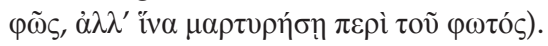

This horizontal relay is reflected by the distinction between light and witness of the light. While the latter is the radiation or the consequence of light, the former is the light source, which resides with the Logos. It is reminiscent of the light

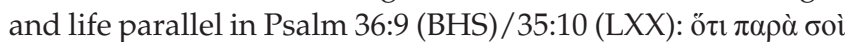

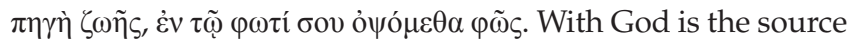
of life, in his light we see light. While the source of light belongs to the realm of God, humanity is able to observe $\varphi \tilde{\omega} \varsigma$ as a result. Similarly, in the prologue, John becomes a witness of the light ( $\varphi \omega \tau$ ósn genitive) and testifies about it to the individual men and women who listen to his message. However, as the observable spiritual light is a direct radiation or perhaps emanation of the Logos, exposing oneself to its rays brings into direct contact with the life-giving Logos. So the Word generates light and this provides life on earth. In the nominative sense $\varphi \tilde{\omega} \varsigma$ belongs to God as the source. When the Baptist is portrayed in the context of horizontal testimony, however, he is described to have $\varphi \omega \tau$ ós. Later in the Gospel,

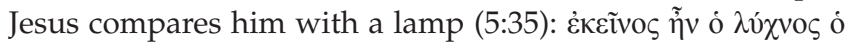

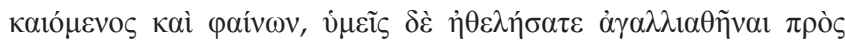

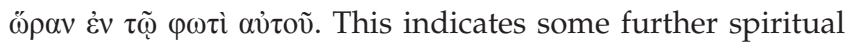
parallelism between the Logos and his herald. Just like the incarnation of the Logos provided just a temporary presence on earth, John the Baptist's presence and witness on earth are

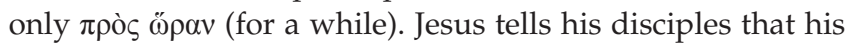
own presence as light of this world is going to have similar restrictions. This is already intimated by the particle ö $\tau \alpha v$ in

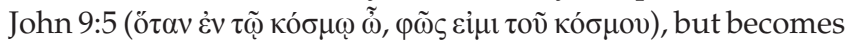
obvious in chapter 12:35-36 where Jesus warns them that his light is only going to be with them for a short while: ह̌兀ı $\mu$ ıрòv

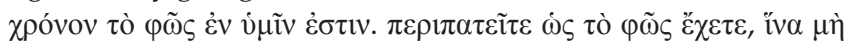

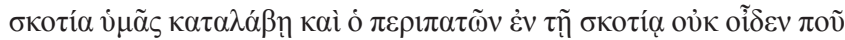

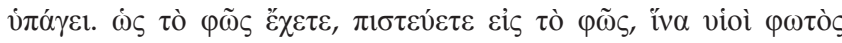
$\gamma \varepsilon \dot{v} \eta \sigma \theta \varepsilon$. As long as they have the light, they should trust it and receive its guidance.

The ultimate result of the Light and its testimony on earth is changed human lives. Those who trust the light and use it for 


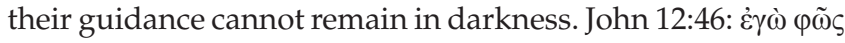

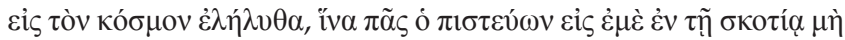
$\mu \varepsilon i$ in. Spiritual light is received by paying heed to Jesus's

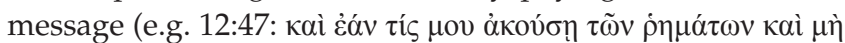
$\varphi v \lambda \dot{\alpha} \xi \eta)$. Friendship with Jesus is described in terms of

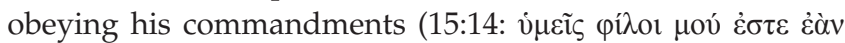

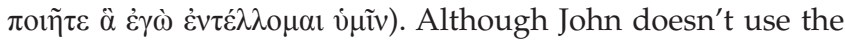
actual phrase 'kingdom of God' often (cf. 3:3, 18:36), in this respect the fourth gospel is not different from the other gospels and Acts in its emphasis on the proclamation of the Kingdom of God. The Logos is both Creator and Lord, who is presented as the Son of God and the King of Israel (cf. 1:50, 12:13-15, 19:12-15). This echoes the Mosaic notion that light is produced and presented not merely for human convenience, but that God should be pleased. In other words: not just a witness to humanity, but particularly also witness and ceremonial service before God, whether it affects humans in any way being of a secondary concern. In Exodus the Aaronic priesthood was commanded to have a perpetual light, fuelled by high grade olive oil, before the ark in the 'tabernacle of testimony' (Ex 27:20-21). This was to be a perpetual light, eternally burning from one generation to the next. Interestingly, there is an early tradition that places the apostle John in this priestly tradition, probably even wearing the oracular ephod (H.E. 3.31.2-3, cf. 3.39.6): John, who was both a witness and a teacher, who reclined upon the bosom of the Lord, and being a priest wore the sacerdotal plate. He also sleeps at Ephesus. ${ }^{7}$

\section{Parallelisms and revelatory concepts of John 1:1-18 in their Greek cultural context \\ Early church: John in Greco-Roman culture of Ephesus region}

The previous section considered the prologue in the textual context of the fourth gospel and Biblical Literature. An analysis showed the Logos to function as Creator and Revealer, while diverse parallel communicative levels or spheres of function were identified. However, the revelatory concepts of John 1:1-18 have a non-literary context as well, in the historical Greco-Roman environment where the gospel was written (cf. Irenaeus Adversus Haereses 3.1-2, Eusebius Historia Ecclesiastica 3.1, 3.20.10-11). ${ }^{8}$

Much has been written about the Roman imperial cult and the hardships implied for John's readership in Asia Minor

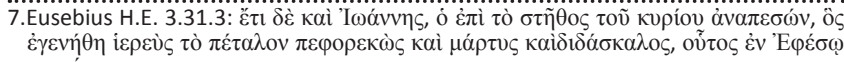
кєкоі́ $\mu \eta \tau \alpha l »$.

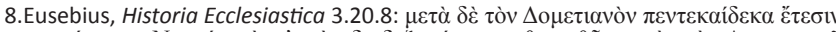

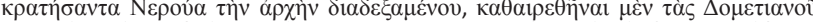

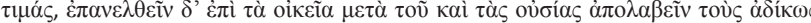

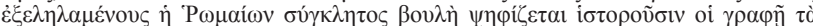

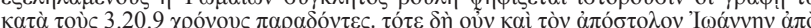

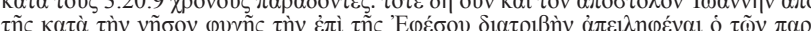

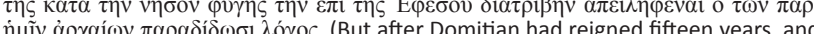

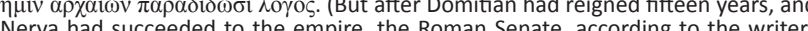
Nerva had succeeded to the empire, the Roman Senate, according to the writer that record the history of those days, voted that Domitian's honours should be cancelled, and that those who had been unjustly banished should return to their homes and have their property restored to them. It was at this time that the apostle John returned from his banishment in the island and took up his abode at Ephesus, according to an ancient Christian tradition.) (e.g. Cassidy 2015:21), R.J. Apart from this, the cultural setting for this gospel was Greek.

Eusebius also quotes a tradition preserved in Clemens of Alexandria, which points to a continued ministry in Ephesus after John's exile at Patmos (H.E. 3.23.6-7). According to Polycarp (Eusebius, Historia Ecclesiastica 4.14.6) John was in the habit of visiting bath houses with his Christian friends, embracing Greco-Roman culture in that respect. ${ }^{9}$

One of John's motivations for also writing a gospel account apparently was that he felt that he had more stories to share on the life of Jesus before the execution of John the Baptist (H.E. 3.24.11-14). These first acts that Eusebius refers to

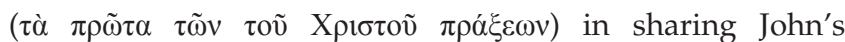
motivation to write his Gospel, the creative deeds of the Logos before all time, as well as his incarnation, seem to have been part of the Apostle's considerations. ${ }^{10}$

Quoting from a letter by Polycrates (c. 130-196 AD) to Victor, Eusebius also places John's death and burial in Ephesus (H.E. 3.31.2-3, cf. 3.39.6).

This cursory overview shows that the earliest Christian sources point to a Greco-Roman context for the fourth gospel. About Ephesus they are as unanimous as they are old (2nd century) and geographically spread: Western Europe (Irenaeus), Asia Minor (Polycrates), and Egypt (Clemens Alexandrinus). Otherwise, this tradition is confirmed by subsequent history and archaeology, ${ }_{1}^{11}$ which e.g. places the site of John's tomb in Ephesus (cf. Plommer 1962:124).

\section{Phoebus Apollo in the Ephesus region Oracular centre of Apollo worship}

In the 1st century, all of the main centres of Apollo worship, except for Delphi, were concentrated around Ephesus, in what is now halfway western Turkey. Apollo and his twin sister Artemis were quite popular and their worship had old papers in this region. Ephesus prided itself in the great temple of Artemis, one of the wonders of the world (cf. Acts 19); while Clarus (K $\left.\lambda \alpha \dot{\rho} \rho \rho_{)}\right)$to the northwest had an important Apollo sanctuary, which also served as oracle. Nearby Didyma to the south was even more important. It boasted the second centre of Apollo worship in the Greek world after Delphi. But the office differed in that the prophetess was annually appointed, while in Delphi it was an office for life (Parke 1986:124). The technicalities of the inspiration process

9. Eusebius, Historia Ecclesiastica 4.14.6 also confirms John's residence in Ephesus and his immersion in Greco-Roman culture, when he relates an anecdote from Polycarp about the apostle, who fled from the bathhouse because of the presence of a

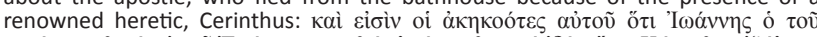

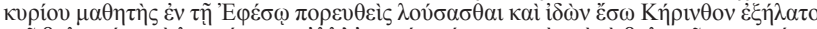

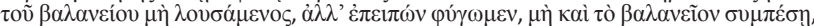

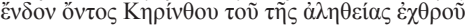

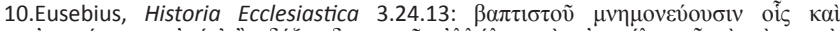

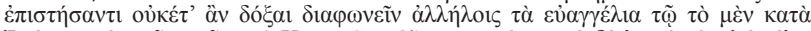

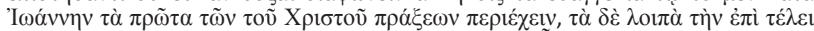

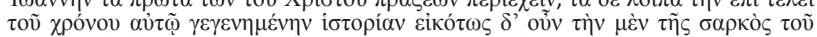

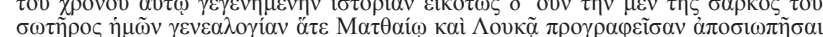

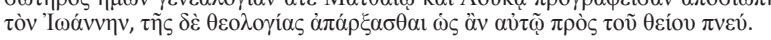

11.Most of the archeological data for the ruins of St. John's Church in Ephesus, on the supposed site of the apostle's tomb, are summarised by H. Plommer (1962:119-129). 
remain unclear, but scholars speculate it could be connected to the ancient spring on the site. This cultic centre was also known under the name Branchidai, the descendants of Brachos, a family who ran the place for many generations in a very distant past (cf. Curnow 2004:133). Strabo describes the site in his Geographica (14.1.4-5):

So much, then, on this subject. But I must again go over the several parts in detail, beginning with the principal places, those where the foundings first took place, I mean those round Miletus and Ephesus; for these are the best and most famous cities. Next after the Poseidium of the Milesians, eighteen stadia inland, is the oracle of Apollo Didymeus among the Branchidae. [Note] It was set on fire by Xerxes, as were also the other temples, except that at Ephesus. The Branchidae gave over the treasures of the god to the Persian king, and accompanied him in his flight in order to escape punishment for the robbing and the betrayal of the temple. But later the Milesians erected the largest temple in the world, though on account of its size it remained without a roof. At any rate, the circuit of the sacred enclosure holds a village settlement; and there is a magnificent sacred grove both inside and outside the enclosure; and other sacred enclosures contain the oracle and the shrines. Here is laid the scene of the myth of Branchus and the love of Apollo. The temple is adorned with costliest offerings consisting of early works of art. Thence to the city is no long journey, by land or by sea. ${ }^{12}$

The Apollo oracle was known to be consulted by kings in the time of Herodotus (Historia 1.46) and was also patronised by Seleucis I (c.300BC) and Emperor Trajan (53-117AD). Seleucis returned its famous bronze Apollo statue after it was stolen by the Persians (cf. Pausanias, Description of Greece 1.16.3). The sanctuary also contained a 'chresmographion', an oracle hall where the responses of the god to human enquiries were recorded.

Like Delphi's, the Oracle in Didyma worked with a human agent, an inspired prophet or prophetess who opened himself to Apollo as the god of inspired prophecy (Chappell 2006:346). Herodotus (1.46), who usually refers to Didyma as 'Branchidae in the Milesian country' (oi $\delta \dot{\varepsilon} \tau \tilde{\eta} \varsigma$ Mi $\lambda \eta \sigma i ́ n \varsigma \dot{\varepsilon} \varsigma$ B $\rho \gamma \chi\{i \delta \alpha \varsigma)$, does not describe the practices in detail, probably because the oracle is not known to have issued major political advice. Surviving inscriptions are the main source for establishing the kind of consultations that were made at Didyma (cf. Morgan 1989:23-24).

\section{Cultural unity of Ephesus/Miletus/Didyma region}

Ephesus and Didyma were quiteclose, not only geographically, but also culturally and historically. Didyma was politically

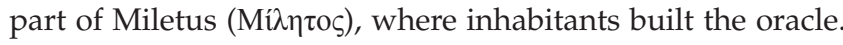

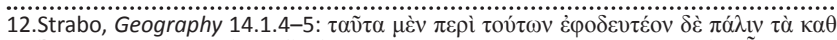

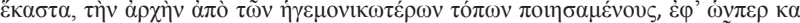

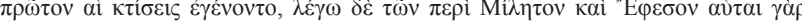

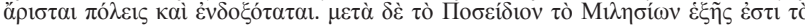

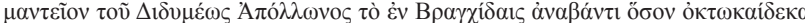

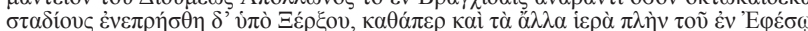

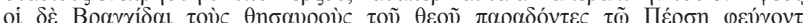

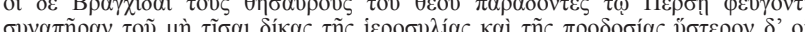

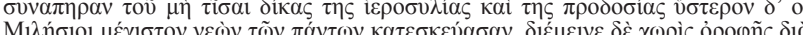

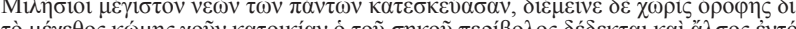

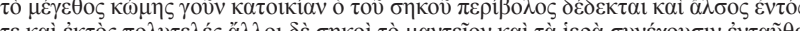

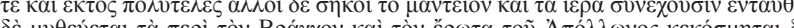

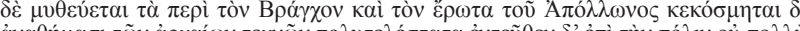

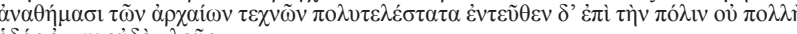
ódó
Miletus effectively functioned as the harbour of Ephesus (cf. Acts 20:17-38, 2 Timothy 4:20), so that the commercial and cultural ties within this region are apparent. When St. Paul was active in Ephesus, this did not remain a local affair, but resulted in reaching the entire province of Asia as a result (see Ac 19:10, 20; 1 Cor 16:9).

Also, the two centres were religiously intertwined, as both Apollo and his sister Artemis were worshipped in both places. In Didyma excavations have revealed a temple of Artemis near to that of the more prominent Apollo temple. Interestingly, both sanctuaries in Didyma were built on the sites of ancient springs (Tuchtelt 1991:90). The very name of

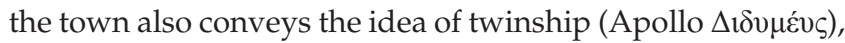
which refers to these divine twins. Although a minor oracular sanctuary to Apollo in Ephesus only dates back to the 2nd century $\mathrm{AD}$, the long established oracle at Claros was not far away, and neither was the Miletian one in the south. Herodotus indicates that the oracle in Didyma was used for consultation by the whole region, including the citizens of Ephesus (Historia 1.157-158):

The Cymaeans resolved to make the god at Branchidae their judge as to what course they should take; for there was an ancient place of divination there, which all the Ionians and Aeolians used to consult; the place is in the land of Miletus, above the harbour of Panormus. The men of Cyme, then, sent to Branchidae to inquire of the shrine what they should do in the matter of Pactyes that would be most pleasing to the gods; and the oracle replied that they must surrender Pactyes to the Persians. When this answer came back to them, they set about surrendering him. But while the greater part were in favour of doing this, Aristodicus son of Heraclides, a notable man among the citizens, stopped the men of Cyme from doing it; for he did not believe the oracle and thought that those who had inquired of the god spoke falsely. ${ }^{13}$

\section{Parallelism between the Johannine Logos and Apollo Phoebus}

\section{Difference}

Before one starts a comparison of deities in different religions, it is important to briefly consider the limitations of such an enterprise. Despite the parallelisms that will become obvious in this section there is sufficient discontinuity in religious context and definition to prevent endorsement of the thesis that the Logos was a Christian remake of a Greek deity. First and foremost, although Apollo is part of a pantheon of gods, the Johannine Logos functions in a monotheistic setting. Secondly, one of the important roles that John claims for him is that of the Creator of all things. This role is not claimed for Apollo. He arrived on the scene much later. If anything, he stole the oracular site at Delphi from the earth goddess Gaia. In Greek mythology she was the personification of this planet

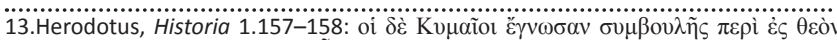

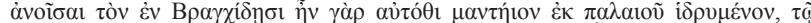

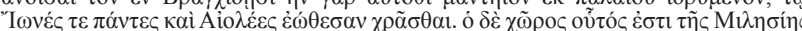

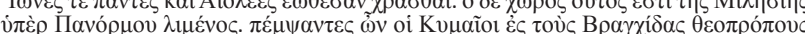

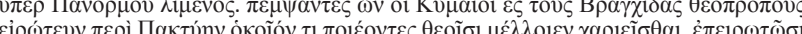

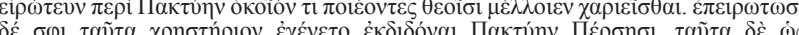

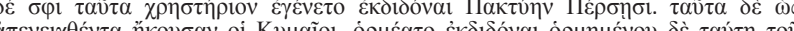

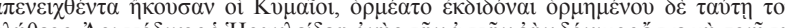

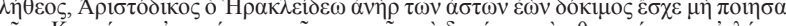

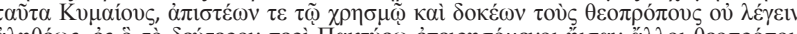

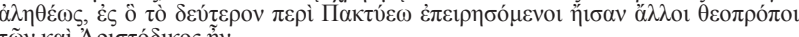

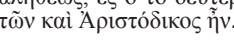


and its fertility. Her marriage with Uranus (earth and space) produced the Titans, Cronus, and other divine and primordial beings. In other words, unlike the Logos, Apollo is far removed from the era of creation and has no claims on humanity as a creator. Thirdly, Apollo also does not need incarnation. He appears on earth with a body every now and then, but there is no permanently becoming part of humanity in the Johannine sense. Despite his notoriously unsuccessful love affairs, he always and exclusively continues to belong to the realm of the gods. The Johannine Logos is not a genitor; neither does the incarnation facilitate this. The Logos has no son in the carnal sense, unlike the Apollo of Greek mythology. The Jesus of the gospels is not interested in procreation, producing a family line. The Logos functions only in leaving a spiritual offspring, but even this, according to John, is essentially the province of the Spirit. He gives the sort of life that cannot be produced by the body (Jn 6:63).

\section{Apollo, light, and revelation}

This being said, there are parallelisms between Apollo and the Johannine Logos, which would have made several characteristics of the Logos sound familiar to 1st century Greek in the Ephesus region and elsewhere. As communication between God and humanity was a central idea in the prologue, it should be noted that Apollo was primarily worshipped as a god who responded to human enquiries. Almost, if not every, Apollo sanctuary was also an oracular site. This was for a reason, as he was known as the god of light and prophecy. All ancient Apollo sanctuaries - Delphi, Delos, or Didyma (all dating back to the 8th century BC), worshiped him as the god of light with prophetic insight that could be useful to those who consulted him.

To reflect this light connection, the Greeks gave him the epithet Фoíßo (Latin: Phoebus), bright, radiant, or pure. This title is associated with the prophetic oracle in Delphi. Plutarch (De E apud Delphi 388-389, cf. 393.C) says that the more enlightened call him Phoebus because of his purity and stainlessness, so the epithet Фoíßoç in itself is not sufficient to establish the connection with light, although Greeks and Romans used it in its Greek and Latin form to refer to Apollo as the god of light. Perhaps Phoebus was to denote the cleansing, purifying powers of the artificial light at the time: fire. It is probably not a coincidence that 1 John 3:3 states: $\kappa \alpha i$

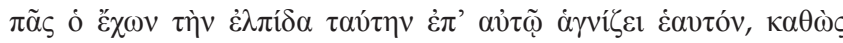

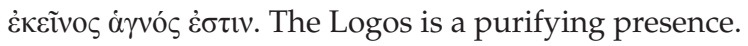

Otherwise the association of Apollo with light was nonambiguous, as he was also called Air $\lambda \eta \dot{\tau} \eta$ (light of the sun) and even directly "H $\lambda_{1}$ o $\varsigma$ and $\operatorname{sol}$ (sun). This direct identification with the sun was widespread, although it was condemned by Plutarch (De E apud Delphi 393.D). To stress Apollo's prophetic abilities, he was also referred to as Apollo Mavııкós.

Although both light and revelation are prominent in Apollo worship, the two are connected in a different way than in the Johannine Logos with its clear connection between light and prophetic revelation. Light in the sense of spiritual illumination seems to be lacking in the religious imagery around Apollo. Although he radiates purity, this is not the general light with its disclosing properties that one finds with the Johannine Logos. Although Apollo has light too, this is more in the sense of ritual purification than revelation of the divine will. For John's gospel, light and revelation go together, but with Apollo these are separate qualities, although they do belong to one another at a secondary level. Plutarch makes this clear when he compares Apollo's prophecy with a deflected ray of light that is captured in the vehicle of poetry, as oracles were often delivered in verse (De Pythiae Oraculis 407E). So although not with the same intensity, still with a measure of the same symbolism, Phoebus Apollo is also the revealer. According to Euripides he carries this trait par excellence, because Apollo fears neither the gods, nor the people who come to make enquiries of him.

Euripides (Phoenissae 958, cf. Plutarch, De Pythiae Oraculis 407D):

The man who practices the prophet's art is a fool; for if he happens to give an adverse answer, he makes himself disliked by those for whom he takes the omens; while if he pities and deceives those who are consulting him, he wrongs the gods. Phoebus should have been man's only prophet, for he fears no one. ${ }^{14}$

Phoebus and prophecy go together. Aeschylus makes that

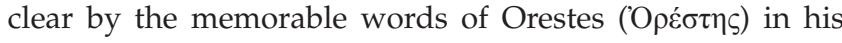
Eumenides 740: 'O Phoebus Apollo! How will the trial be

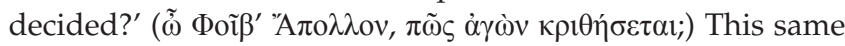
connection between Phoebus and divine pronouncements comes through in the opening verses of the tale that describe Jason's quest for the Golden Fleece (Apollonius Rhodius, Argonautica 1.1):

Beginning with thee, O Phoebus, I will recount the famous deeds of men of old, who, at the behest of King Pelias, down through the mouth of Pontus and between the Cyanean rocks, sped wellbenched Argo in quest of the Golden Fleece. Such was the oracle that Pelias heard, that a hateful doom awaited him to be slain at the prompting of the man whom he should see coming forth from the people with but one sandal. ${ }^{15}$

So, despite the difference in scope and intensity with the Johannine Logos, revelation and the symbolism of light are present with Apollo. There is a level of parallelism that would have been apparent to Greek people in the Ephesus region. They were familiar with the idea of a god who reveals divine will and is referred to as the god of light at the same time.

\section{Life, healing, and well-being}

Apollo was also the Greek god that was known for his healing powers. This was not an activity separate from his oracular

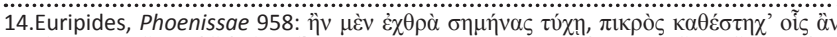
oỉ

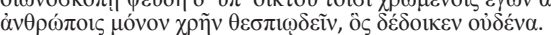

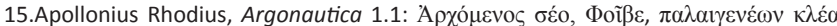

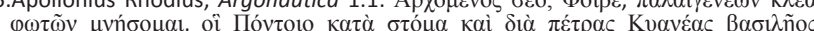

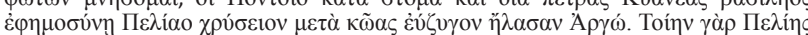

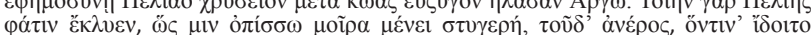

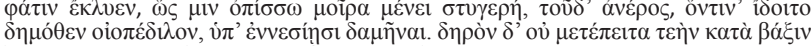

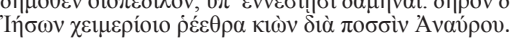


role. His mantic abilities operate jointly with his healing powers. From Homeric times, Apollo was considered a god who could strike with disease, but also cause the pestilence to leave (Homer, Iliad 1.60-75):

But come, let us ask some seer or priest, or some reader of dreams-for a dream too is from Zeus-who might say why Phoebus Apollo is so angry, whether he finds fault with a vow or a hecatomb; in hope that he may accept the savour of lambs and unblemished goats, and be willing to ward off the pestilence from us. ${ }^{16}$

The combination of oracular and healing components is particularly visible in the Ephesus region, as Didyma was both an oracular and healing site. Significantly, Strabo in his Geography (c. 64BC - 24 AD) points out that Apollo was especially worshipped and consulted for his healing powers. ${ }^{17}$

Apollo and his twin sister were approached for bodily wellbeing, to keep calamity and disease at bay. There are profound parallels with the healing qualities of the Johannine Logos. Jesus pronounces a healing oracle to the official's son (John 4:50), heals a long-term cripple at Bethesda (5:8-9), gives sight to a man born blind (John 9:1-7), and famously raises Lazarus from the dead (11:38-44). Jesus' comparison of himself with the copper snake that was lifted in the desert to bring healing to the Israelites (John 3:14) would have been readily understood in this cultural context and to some extent familiar in its concepts and imagery to the Greeks of the Ephesus region. Since times immemorial (cf. Homer) Apollo had been associated with a snake, and his son Asclepius had the symbol of a single snake wrapped around a staff, not unlike the Mosaic serpent on a pole. He also inherited Apollo's qualities of healing powers, plus protection against sickness and disease (cf. Apollonius Rhodius, Argonautica 2.500). It is perhaps no coincidence that the only reference in the New Testament to the Mosaic snake on a pole is found in John's gospel.

So also at the level of life and healing there are several parallels between Apollo and the Johannine Logos. Phoebus Apollo reveals and heals. ${ }^{18}$

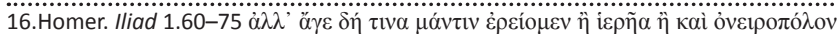

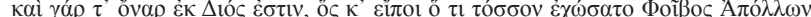

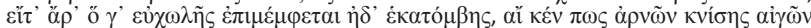

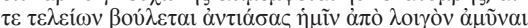

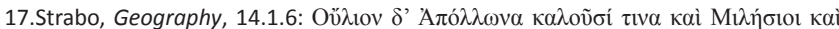

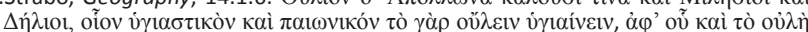

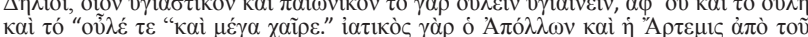

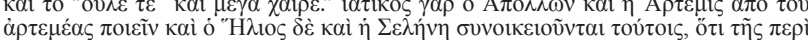

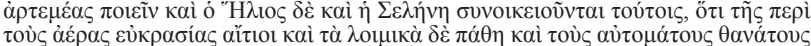

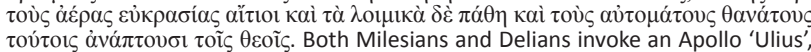

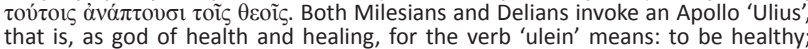
whence the noun 'ule' and the salutation, 'Both health and great joy to thee'; for Apollo is the god of healing. And Artemis has her name from the fact that she makes people 'Artemeas' (safe and sound). And both Helius and Selene are closely associated with these, since they are the causes of the temperature of the air. And both pestilential diseases and sudden deaths are imputed to these gods.

18. From the 2 nd century it became apparent that the oracles were in such decline that they even pronounced the end of pagan religion, or were at least attributed to do so. Beatrice (1997:5) defines these as 'special oracular utterances, mainly by Apollo and Hekate about the nature of the godhead, which became common in the pagan world from the end of the 2 nd century CE to satisfy the increasing demand for religious certainties'. See Pier Franco Beatrice (1997:3-22). These oracles of for religious certainties. See Pinially functioned in the defence of paganism against Christianity (cf. Apollo initially functioned in the defen
Augustine, De Civitate Dei, ch.17-19).

\section{Conclusion}

A philological analysis of John 1:1-18's textual context emphasises the revelatory emphasis of the fourth gospel. The Logos as the divine Creator denotes his special relationship to this world and humanity. Divine communication takes place in a setting that is discontinuous with the first creation, the Logos becomes incarnate in a world that is in rebellion against God, a place of darkness, devoid of Divine revelation where his own receive him not. It is God's speech, the fruit of his breath or spirit, that created in the beginning and recreates in John's gospel. As revealing light the Logos also provides insight for humanity. In this way the Logos comprises the Old Testament notion on light, revelation, life, and healing, with particular parallels in Genesis, Exodus, Psalms, Wisdom, and Jesus Sirach. Light, life, and revelation function at equal semantic levels, whereas the communication strategies of the Logos are facilitated by the work of Father and Spirit. Because of its theological continuity this parallelism between the prologue and biblical wisdom literature may be regarded as derivative. The parallelism between the prologue and the Greek oracle religion, on the other hand, is functional. Although there is theological discontinuity, John uses the familiarity of his hearers with revelatory concepts to proclaim his biblical message in a Greco-Roman setting. The prologue's concept of a God of light who reveals (communicates) and heals connects in a very basic way with the Greek notion of Phoebus Apollo and the Ephesus region, where a revelatory message of light, life, and healing was long since associated with the gods. Both the derivative parallelism with the Septuagint and the functional parallelism with the Apollo worship contribute to the unique revelatory emphasis of John's gospel.

\section{Acknowledgements Competing interests}

The author declares that he has no financial or personal relationships which may have inappropriately influenced him in writing this article.

\section{References}

Aeschylus, 2010, Eumenides, Perseus Project Texts Loaded under PhiloLogic Greek and Latin Morphology (Release \#2), April 2010.

Anderson, P.N., 2008, in R. Bauckham \& C. Mossel (eds.), The Gospel of John and Christian theology, Wm. B. Eerdmans Publishing, Grand Rapids.

Apollonius Rhodius, 2010, Argonautica, Perseus Project Texts Loaded under PhiloLogic Greek and Latin Morphology (Release \#2), April 2010.

Ashton, J., 2014, The Gospel of John and Christian origins, Fortress Press, Minneapolis.

Bauckham, R. \& Mosser, C., 2008, The Gospel of John and Christian theology, (first St Andrews Conference on Scripture and Theology, 2005), Eerdmans, Grand Rapids.

Bauer, W., Aland, K. \& Aland, B., 1988, Wörterbuch zum Neuen Testament, Walter de Gruyter, Berlin.

Beatrice, P.F., 1997, 'Monophysite christology in an oracle of Apollo', International Journal of the Classical Tradition 4(1), 3-22.

Borgen, P., 1972, 'Logos was the true light: Contributions to the interpretation of the prologue of John', Novum Testamentum 14(2), 115-130.

Brenton, L.C.L., 1994, The Septuagint with Apocrypha: Greek and English, Hendrickson, Peabody.

Bultmann, R., 1941, Das Evangelium des Johannes, Kritisch - exegetischer Kommentar über das Neue Testament, Vandenhoeck \& Ruprecht, Göttingen.

Cassidy, R.J., 2015, John's Gospel in new perspective: Christology and the realities of Roman power (Johannine monograph), Wipf and Stock, Eugene, OR (previously published by Orbis in 1992) 
Chappell, M., 2006, 'Delphi and the Homeric Hymn to Apollo', The Classical Quarterly $56(2), 331-348$.

Curnow, T., 2004, The oracles of the ancient world, a comprehensive guide, Duckworth, London.

Endō, M., 2002, Creation and Christology: A study on the Johannine prologue in the light of early Jewish creation accounts, Mohr Siebeck, Tübingen.

Euripides, 2010, Phoenissae, Perseus Project Texts Loaded under PhiloLogic Greek and Latin Morphology (Release \#2), April 2010.

Eusebius, Historia Ecclesiastica, (Migne's Patrologia Graeca, 2006 edition, University of Aegean).

Evans, C.A., 1993, Word and Glory: On the exegetical and theological background of John's prologue (JSNT supplement series 89), JSOT Press, Sheffield.

Giblin, C.H., 1985, 'Two complementary literary structures in John 1:1-18', Journal of Biblical Literature 104(1), 87-103.

Harrington, D.J., 2005, 'Qumran literature and the Johannine writing, response to Joseph A. Fitzmyer', in J.R Donahue (ed.), Life in abundance: Studies of John's Gospel in tribute to Raymond E. Brown, S.S, p. 136, Order of Saint Benedict, Collegeville.

Herodotus, 2010, Historia, Perseus Project Texts Loaded under PhiloLogic Greek and Latin Morphology (Release \#2), April 2010.

Homer, 2010, Iliad, Perseus Project Texts Loaded under PhiloLogic Greek and Latin Morphology (Release \#2), April 2010.

Liddell, H.G. \& Scott, R., 1996, A Greek-English lexicon, Clarendon Press, Oxford.
Lincoln, B., 1996, 'Gendered discourses: The early history of "Mythos" and "Logos", History of Religions 36(1), 1-12.

Martin, F. \& Wright, W.M., IV, 2015, The Gospel of John (Catholic commentary on sacred scripture), Baker, Grand Rapids.

Miller, Ed. L., 1993, 'The Johannine origins of the Johannine Logos', Journal of Biblical Literature 112(3), 445-457.

Morgan, C., 1989, 'Divination and society at Delphi and Didyma', Hermathena 147, 17-42.

Parke, H.W., 1986, 'The temple of Apollo at Didyma: The building and its function', The Journal of Hellenic Studies 106, 121-131.

Phillips, P.M., 2006, The prologue of the Fourth Gospel: A sequential reading (The Library of New Testament Studies), T\&T Clark, New York.

Plommer, H., 1962, 'St. John's Church, Ephesus', Anatolian Studies 12, 119-129.

Plutarch, De E apud Delphi, (Moralia, vol. 5, Loeb Classical Library with translation Frank Cole Babbitt), Harvard University Press, Cambridge.

Strabo, 2010, Geography, Perseus Project Texts Loaded under PhiloLogic Greek and Latin Morphology (Release \#2), April 2010.

Tuchtelt, K., 1991, 'Drei Heiligtümer von Didyma und ihre Grundzüge', Revue Archéologique, Nouvelle Série 1, 85-98.

Van den Broek, R., 1979, 'The Authentikos Logos: A new document of Christian Platonism', Vigiliae Christianae 33(3), 260-286.

Van Tilborg, S., 1996, Reading John in Ephesus, Brill, Leiden.

Wolfson, H.E., 1951, 'Clement of Alexandria on the generation of the logos', Church History 20(2), 72-81. 